\title{
'SPEAK OUT' - ISSUES IN PARTICIPATORY MATERIALS DEVELOPMENT
}

Zannie Bock

University of the Western Cape

This article outlines the development of a beginner English course called 'Speak Out' for adults in Adult Basic Education and Training classes in the early 1990s. The course uses an innovative roleplay methodology which builds on the experiences and language knowledge of the adult learners. It was conceptualised and developed within a participatory approach to adult learning and materials development. The article explores the tension between the ideals of the participatory approach and the constraints exerted by contextual and other factors. The article begins with an introduction of the context within which the materials were conceptualised, then offers a brief overview of the participatory approach, and then considers the following aspects of the 'Speak Out' course: the language learning methodology, issues of teacher competence and development, and lastly, the materials development process itself.

Hierdie artikel beskryf die ontwikkeling van ' $n$ beginnerskursus vir Engels, getitel 'Speak Out'. Dit is ontwerp vir volwassenes in klasse binne ' $n$ Volwasse Basiese Onderrig en Opleiding-program in die vroeë 1990s. Die kursus maak gebruik van innoverende rolspel as ' $n$ metode wat spesifiek aansluit by die ervarings en taalkennis van volwasse leerders. Dit is gekonseptualiseer en ontwikkel as deel van ' $n$ deelnemende benadering tot die opleiding van volwassenes en die ontwikkeling van hulpmiddels. Die artikel ondersoek die spanning tussen die ideale van ' $n$ deelnemende benadering en die beperkinge wat opgele word deur kontekstuele en ander faktore. Die inleiding van die artikel gee ' $n$ uiteensetting van die konteks waarbinne die hulpmiddels gekonseptualiseer is. Dan volg ' $n$ kort oorsig oor die deelnemende benadering, en die volgende aspekte van die 'Speak Out'-kursus word oorweeg: die metodologie van taalaanleer, kwessies rondom onderwysers se vaardighede en ontwikkeling, en laastens, die proses van hulpmiddel-ontwikkeling self.

\section{BACKGROUND AND CONTEXT}

'Speak Out' was developed by a non-governmental organisation called Uswe' which was first established in 1981 to train teachers of adults who attended informal classes run by the churches and who wished to acquire English (additional ${ }^{2}$ language) literacy skills. The initial inspiration for the Uswe approach was Freirean. Paulo Freire developed a problem-posing approach to first language literacy in his work with oppressed communities in Brazil in the 1960s (see, for example, Freire 1972 for a fuller description). His approach was based on the belief that the acquisition of literacy should accompany the development of learners' 'critical consciousness' about their position in society as well as the possibilities for social change. The content of his literacy classes centred on issues in his learners' lives and the ways in 
which they could achieve some control over some of these issues and work for changes in their social, political and economic environments. His approach inspired the worldwide popular education movement of the 1970s (Clifford \& Kerfoot, 1992: 196) and initially Uswe adopted this approach. However, Freire's approach was developed within a first language literacy context and was based on an assumption of fluency in the language of enliteration, and soon proved limited for a context in which people were acquiring literacy skills in an additional language.

Uswe therefore began developing an approach which kept the popular education principles of Freire, but was informed by theoretical developments in applied linguistics such as discourse based approaches to language, communicative language teaching and task-based, learnercentred curricula. The approach which emerged can be described as 'learner-centred', 'process-oriented' and 'participatory' (Clifford \& Kerfoot, 1992: 202).

The 1980s were a period of intense political repression in South Africa as the pressures for democracy from anti-apartheid forces both within and outside the country intensified. Uswe and other progressive organisations who were working for political change in South Africa, were increasingly subjected to state harassment and repression as they were viewed as a political threat by the state. In line with this, Uswe shifted away from a focus on English only towards a broader curriculum which could encompass a critical and political dialogue more fully. In addition, in response to research (e.g. Cummins \& Swain, 1986) which highlighted the primacy of the first language for literacy and learning, Uswe set up first language literacy classes as a parallel strand to the English communications strand.

In the early 1990s, as part of a national movement to prepare for a post-apartheid educational system, Uswe's goals became focused on the development of skills for democratic participation in all spheres of life. Uswe began developing an English communications curriculum for adults in Adult Basic Education (ABE) classes. Although the focus was English communications, the materials adopted a content-based approach in an attempt to offer a basic general education together with language and literacy development.

At that time, organisations working for political change in South Africa anticipated that ABE (later ABET, or Adult Basic Education and Training ${ }^{3}$ would be a high priority programme under the new democratic government. Establishing a reliable estimate of the number of people in need of basic education has been extremely difficult in South Africa, where, for historical and political reasons, no accurate census of the population was available until 1998. The figures have ranged from 5 - 15 million, although research from 1996 suggests that the number of people who are 'functionally illiterate' (i.e. have less than 7 years of schooling) is probably closer to 7.4 million (Harley et al., 1996).

In the early 1990s, draft educational policy for the post-apartheid South Africa envisaged a national system for ABET which would be capable of mass delivery and with the aim of reaching all those who had not had access to basic education under the apartheid government. This included the development of a national system of levels and outcomes for ABET, as well as a system of nationally accredited qualifications. The Uswe curriculum project was conceptualised within this context.

'Speak Out', the course which is reported on in this article, forms part of the Uswe English communications curriculum. It is the first in a series of courses which aim to develop learners' English from little or no knowledge of the language to an intermediate level 
equivalent to about nine years of formal schooling. It focuses on the development of English oral skills, as a foundation for English literacy development. It was published by a national publisher, Sached Books, a division of Maskew Miller Longman, in 1997. The author of this article is one of the materials writers.

'Speak Out' aims to develop learners' confidence to use the English they may already have acquired and further develop their communicative competence in English, particularly their oral competence. At the same time, it attempts to integrate learning English with an exploration of content that might be relevant and useful to the learners. It explicitly explores issues of power linked to the use of English, in light of the role of English in South Africa as the predominant language of 'power'.

The final published course consists of

- $\quad 2$ workbooks for learners, containing worksheets for each lesson;

- $\quad 2$ handbooks for teachers, with lesson plans for each lesson;

- $\quad$ an audio-tape for the listening exercises;

- posters for each topic.

The course covers four topics which are drawn from two areas of knowledge: health and income-generation. The topics are:

- Health: Burns, TB and nutrition

- Work: Making money (informal sector), Looking for work (formal sector)

The above is a description of the end-product; the focus of this article is on the rationale and process behind this product, and it is to this that we now turn.

\section{'SPEAK OUT' AND PARTICIPATORY MATERIALS DEVELOPMENT}

'Speak Out' attempts to implement many of the principles of the participatory approach, both in terms of the methodology and the materials development process.

The participatory approach is guided by the over-arching belief that learning is most powerful when it relates directly to learners' lives and concerns. According to Auerbach (1992), the participatory curriculum 'has to be built on the particular conditions, concerns, and contributions of specific groups of participants at a particular point in time' (Auerbach, 1992:13). It cannot be developed by the teacher before he or she has met the learners.

The curriculum development process begins with an extensive needs analysis during which the teacher attempts to uncover themes of interest to the learners. Themes emerge through discussion which can be prompted by activities such as the telling and writing of life stories and the use of photographs, pictures and 'significant objects' (Auerbach, 1992:49) or simply through spontaneous conversation before or after class. These themes then form the basis for the curriculum which explores each in more detail using a variety of 'tools'. A 'tool' can refer to any 'visual, or non-visual, verbal or non-verbal, textual or non-textual ' (Auerbach, 1992:62) means used to generate reflection, dialogue and critical thinking. Increasingly, through the learning process, the goal is to move towards learner-created tools. The teacher and the learners move through a learning process of validating learner experience and 
'collaboratively constructing knowledge' (Auerbach, 1992:49). This culminates in some kind of 'social transformation' or 'action', which could be an obvious, collective, possibly political action, such as writing a letter of complaint or participating in a protest, or simply an individual, invisible change - 'the cumulative building of confidence, validation of experience, and reflection on context.' (Auerbach, 1992:102).

Language work is integrated with this exploration of themes, and the process of learning is at all times made explicit. In this way, the teachers attempt to empower learners through offering them choices and giving them control over decisions about the learning process.

There are clearly a number of issues to consider with respect to the participatory approach. Firstly, in practice, the ideals of learner-centredness are easily compromised. Rather than following a process of collaborative knowledge construction between teachers and learners, the development of understanding root causes and deciding on appropriate action can easily become teacher-driven. Secondly, within a context of scarce resources, a weak administrative system and the under-development of teachers, participatory education can seem unrealistic a utopian ideal. Thirdly, there is a contradiction between the idea of an open-ended learnerdriven curriculum and the requirements of a national curriculum guidelines with pre-defined outcomes. As far as 'Speak Out' is concerned, there is a fourth contraction between the principles of participatory education and the notion of published materials which fix a particular definition of learner needs, choice of themes and learning process. The extent to which 'Speak Out', in both its process of development and the final product, addresses some of the issues while attempting to implement the principles of the participatory approach is discussed in the remainder of this article.

\section{THE LANGUAGE LEARNING METHODOLOGY}

The course uses an innovative roleplay methodology which is based on a generative model of materials development. Learners are not given pre-written roleplays or conversational routines to learn by heart, but generate their own roleplays in class using the language they already know or through expressing what they want to say in the first language which the teacher then translates into English. In this way, the methodology uses learners' own experiences and language knowledge (both the first language and any English they may know) as a starting point.

The following description is of a class that took place in Crossroads, an informal settlement outside Cape Town in 1993. The class began with a discussion of the learners' own experiences of their children and diarrhoea, moved to a discussion on how they treat it, with the teacher offering advice on 'the way recommended by doctors' and then the generation of a roleplay between a mother whose child had diarrhoea and a health worker. The teacher helped to contextualise the roleplay by asking the learners to reflect on how they think the mother and the health worker might feel and why. She then asked the learners, 'What is the first thing the mother says to the health worker?' and wrote up what they said on newsprint. She tried to stick as closely as possible to their own words, but made small grammatical edits to their sentences. She then asked, 'What does the health worker then say?' and wrote up this response, and so on until the following short roleplay was written: 


\section{$\mathrm{D}=$ Doctor, $\mathbf{M}=$ Mama}
D: Hello Mama.
M: Hello Doctor.
D: What is your name?
M: Nosiphelo Tofile.
D: What is your baby's name.
M: Thembeka.
$\mathrm{D}$ : What is wrong with you baby?
M: My baby has a running stomach.
$\mathrm{D}$ : What else is wrong?
M: She is hot, vomits and has pain in her sides.
D: Please put your baby on the bed. I want to have a look at her. You must give your baby the salt and sugar drink. Come back tomorrow.
M: Thank-you doctor, good-bye
D: Good-bye.

The learners then practised this dialogue, initially as a class, then in pairs.

Roleplays like this one can then become a focus for language development and critical reflection. For example, learners can be encouraged to ask questions such as 'But what is wrong with my baby?' and 'What must I do if she does not get better?', questions which are frequently silenced by language barriers and the pressures of time in a public health care system.

In the case of the above roleplay, the teacher then extended this roleplay in the following way: she role-played the part of the health worker, and the learners responded to her questions as mothers. At the point where the learners/mothers asked her 'What is wrong with my baby', she purposefully mumbled a response and waited to see what would happen. After a few moments of confusion, one of the learners said 'Please repeat, I don't understand' (questions that had already been taught in a previous lesson) and so the teacher was able to create a meaningful context for real language practice and the learners were able to experience how their language learning can be used in real instances of communication.

The roleplays can also provide a means for locating learners' experience within a broader social reality. For example, another group of learners generated the following roleplay - note that these were the learners' own words, reflecting their experiences of the health care system:

\section{$\mathbf{N}=$ Nurse, $\mathbf{P}=$ Parent}

N: Good morning mama

P: Good morning nurse

$\mathrm{N}$ : What is wrong with you mama?

P: Nurse, my child is burnt with boiling water.

N Why did you burn your child? I can't help you, I'm sorry. You mothers don't care about your children. You always burn your children.

P: She pulled the pot off the table.

N: Where were you? Why did you leave your baby with boiling water?

P: Please nurse help me. 
N: Undress your child.

Listen mama, when your child is burnt, pour cold water on the burn. Cover it with a clean bandage. Keep it clean. Remember, never put eggs, sunlight soap or butter on the burn.

P: Thank you nurse.

$\mathrm{N}$ : Come again tomorrow.

P: Bye-bye.

The questions which arise from this then become, 'Why do so many of our children get burnt? Is it really because we are careless?' as well as the opportunity to explore some of the socioeconomic aspects of their living conditions e.g. lack of electricity, use of paraffin and candles. It also provides a context for considering ways of dealing with and challenging, in English, the attitude of the nurse. The materials attempt to support teachers in this process by, for example, suggesting questions for reflection and activities which could lead to some kind of action for change, such a 'Write a letter to your local town council asking for electricity in your homes'.

A pre-written roleplay would not have been able to capture the particular experience reflected in the roleplay above and so would have missed an opportunity to draw on learners' own experience and language knowledge and to link this to broader social issues.

As learners' confidence and communication skills develop, the role-play methodology can expand and develop in numerous ways. The following roleplays were generated over four lessons in response to a letter (published in a magazine) from a farm worker asking for advice with respect to his conditions of work.

\section{W: Workers, F: Farmer}

\section{PART 1}

W: Baas, we want more money.

F: I can't give you more money, because I already give you food for free and you do not pay rent.

W: Yes, but that is not enough. We have families that depend on us.

F: O.K. I hear what you say, but I want to think about it.

$\mathrm{W}$ : When will you give us an answer, Mr Farmer?

F: Am I Mr Farmer to you?

W: No Baas, but we want an answer.

\section{PART 2}

W: Good morning, Baas. We are still waiting for our answer.

F: I have not yet decided on an answer. I will give you an answer soon.

W: O.K. Baas, but we will come back this afternoon. The way you treat us is really bad. We have families that depend on us. We really need something better.

F: Why are you talking like this to me? I am the boss!

$\mathrm{W}$ : We know you are the boss, but we are just asking you to do us a favour. The hours we work are long, but the money is little.

F: Go on with your work. I will see you this afternoon and tell you what I have decided. 


\section{PART 3}

W: Good afternoon, Baas.

F: Good afternoon, I have thought about what you asked. I can give you more bags of meal per month, but I cannot give you more money, because I must still plan my budget.

W: But we need more money. When we get sick and our children get sick we need money for the doctor.

F: Alright, I will give you money, but not this year.

W: O.K. we think we should make a new contract.

F: What new contract? I will get new workers. You can go.

W: O.K. Baas. We have nowhere to go. We were just asking you, and explaining why we need more money.

F: O.K. I hear what you say. Give me a chance to think about it.

\section{PART 4}

W: Good morning, Baas.

F: Good morning.

W: Baas, we are still waiting to hear your answer about what we asked.

F: O.K. I have thought about what you asked me. I will give you more money next month.

$\mathrm{W}$ : How much money will you give us?

F: I will give you R25 more next month, but I will not give more bags of meal.

W: O.K. Baas, thank you for the extra money, but what about the hours?

F: O.K. you must work from 7 a.m. to 6 p.m.

W: That's O.K. What about weekends?

F: What is wrong with weekends?

W: We know we used to work in the weekends, but we have things to do. Please can we work less hours.

F: O.K. in the weekends you come to work from 6 to 8 in the mornings, and 4.30 to 6 in the afternoons.

W: Thank you Baas. We are satisfied.

This series of dialogues offers the potential for exploring a number of issues to do with race, class and power, conditions of employment, strategies for negotiating better conditions, strategies for challenging those in authority as well as attendant risks, etc. Learners could also be asked to reflect on the extent to which the experience recorded by this series resonates with own experiences, for example, 'How did the farm workers negotiate their conditions? [plus list of strategies for them to tick] Would these things work in your workplace?' It is a small step from this kind of guided roleplay to the learners creating and enacting their own mini-dramas.

The approach to language teaching is premised on the belief that learning of linguistic form is best carried out when the focus is on meaning and that language is used and learnt through the completion of communicative tasks. The theoretical rationale for this approach is succinctly summarised by Prabhu in his seminal book, Second Language Pedagogy:

In task-based teaching, lessons in the classroom are not acts of text, or 
language presentation, but rather contexts for discourse creation. The tasks provided in a collection are essentially plans for discourse, and the discourse which actually results in the classroom is shaped as much by learners' reactions as by teachers' intentions, and also by a number of ad hoc coping strategies employed on both sides. 'Materials', in the sense of the language that becomes available to learners, are the actual discourse events that constitute lessons. Further, since those discourse events are likely to be perceived and processed differently by different learners, depending on the degree of their engagement and what they bring to bear on the tasks, materials as learning resources can vary from one learner to another within the same class.

(Prabhu, 1987:95-6)

The role play methodology is consistent with participatory approaches in that it affirms and builds on learners' knowledge and experience and is flexible enough to be adapted to a range of different situations and contexts: role plays can be generated on any topic of interest to learners. An experienced and creative teacher could integrate a range of reading, writing and language activities with a role play on any theme or topic. In addition, it aims to shift some of the power in the classroom from the teacher to the learner. As Auerbach (1992:45) argues,

[I]f teachers formulate and ask all the questions, the traditional power relations of the classroom are reinforced. Letting learners decide what they want to ask gives them some control...

The use of role play had an interesting effect on quiet, shy, predominantly women learners: the materials writer noted that it seemed to provide a space for them to speak English. Learners who had said nothing for weeks would stand in front of the class and enact a rehearsed roleplay with a partner. It appeared that the platform of performance gave them the confidence to speak publicly, or perhaps it was the relative anonymity of an assumed character that gave them that freedom.

'Speak Out' obviously diverges from the principles of the participatory approach in that the curriculum content, process and outcomes are largely pre-determined due to the fact that the material is in a published form and is intended for use by a number of different groups of learners across the country. This 'contradiction' points to a central issue for the materials developers: the need to balance the openness and context-specific nature of the participatory approach with the need for published materials that could be used by often inexperienced and under-qualified teachers and could form part of a national ABET curriculum.

\section{Teacher competence and teacher development}

In South Africa, ABET practitioners experience all the disadvantages of many teachers of adults elsewhere in the world. ABET facilitators have mostly been and are still largely outside any formal state system, with the effect that there are always limited or no resources available, their work is part-time, insecure and badly paid, they frequently receive little or no formal teacher training, and even if they do, their qualifications are not recognised by the state. There are frequently no learning materials or suitable venues for classes and they and their learners have to travel to and from classes at night on public transport, which is not safe in South Africa. The fact that there is so little support and funding means that it is difficult to find and retain highly skilled ABET practitioners. A recent policy decision by the government has prioritised the use of re-deployed teachers from the formal school system who tend to operate in a more traditional chalk-and-talk paradigm. 
Due to the poor availability of libraries or sources of information or even the teacher's own lack of ability to access and organise information clearly, teachers often find it difficult to create their own materials. In addition, the teachers' own English is frequently quite weak as English is an additional language for most of them and their own language training under the previous apartheid education system was inadequate. There is no doubt that experienced and creative teachers with access to the necessary resources can act as 'problem-posers' and facilitate a process of uncovering themes, reflection and construction of new knowledge and understanding, but they are the exception rather than the rule.

So 'Speak Out' has the explicit goal of developing the teachers' own competence and their ability to use the materials flexibly and creatively and ultimately to generate their own materials - by offering structured lesson plans as models of good practice and by including at the end of each lesson a page of key points and questions for reflection. By the end of the course, if teachers have made use of these 'Teacher Talks', they should have developed a deeper understanding of the methodology and be able to adapt the materials to meet the needs of a specific class as well as generate their own material on new themes.

Thus; despite the fact that the content and process of 'Speak Out' is largely pre-selected, structured and sequenced, it seeks to develop the capacity of teachers to facilitate the kind of learner-centred, problem-posing process of participatory education. 'Speak Out' may even result in the development of the teacher's linguistic competence: an Uswe teacher, who had a first language literacy class, reported that her English had improved by the end of the year after using 'Speak Out' to introduce English to her class.

\section{The materials development process}

Another way in which Uswe has attempted to find a 'middle way' between, on the one hand, the ideals of popular education and critical literacy/language awareness movement, and, on the other, published materials has been through a rigorous process of researching needs, workshops, piloting, and the incorporation of both teachers' and learners' comments, writings and concerns into the materials.

'Speak Out' was developed in collaboration with a group of teachers over 3 years and many of the ideas that emerged through this process have influenced and enriched the course.

The themes (referred to as topics in the materials) were identified though pre-course interviews conducted by the materials writer and teachers with groups of adult learners in either English or Xhosa, the local African language in 1992. The needs analysis aimed to uncover the situations and texts for which learners needed a knowledge of English, as well as those they already encountered in English. Learners from ten beginner English and first language literacy classes were interviewed.

The most frequently quoted reasons for wanting to learn English included:

- to fill in forms

- to be able to communicate with white people in town and at work

- to be able to look for employment from English speakers

- to improve chances of employment and promotion at work

- to be able to answer the telephone at work and take down a message

- to communicate with the doctors and sisters at the clinics/hospitals 
- to have access to further education

- to be able to participate in community (e.g., soccer, Women's League) or union meetings which were conducted in English

- to understand when people mix Xhosa and English (Mixed Xhosa is a recognised urban variety of Xhosa) or switched from Xhosa into English ('as they do in some interviews on Xhosa radio' one learner explained).

In answer to the question, 'Do you listen to English radio or TV?', a number of learners responded that although they did not listen to English radio, those who had access to TV said they often watched the Xhosa news at 19:00 and then switched to the English news at 20:00 because it gave so much more information. They said that even though they could not understand what was being said, they enjoyed watching the visuals and comparing it with the coverage on the Xhosa TV channel.

Initially five topics were identified:

- Looking for Work

- Visiting the doctor/clinic

- Nutrition and Health

- Daily Life (shopping, filling in forms)

- The News

Eventually, only the first three were covered in any depth, the fourth was integrated into the first three, and The News was omitted due to length and space constraints as well as consideration of broader curriculum goals (such as appropriate levels of English literacy and coherence with the next Uswe communications course, which had an education and knowledge production theme). Had a sequel to 'Speak Out' been developed, as was originally planned, that course would have taken up a critical media theme.

The final product included two main themes: Work and Health, where Work included both looking for work in the formal sector, as well as working in the informal sector, and Health included an exploration of burns, TB and nutrition, as a preventative measure. The health areas were identified through consultations with doctors and community health workers as some of the most serious health problems faced by working class South Africans. We omitted discussion of HIV/AIDS in this course because we believed that this could be explored more appropriately in the first language classes. Discussion of sexual organs is taboo in many African languages and we were concerned that the use of English would simply have provided an additional barrier which could result in misunderstandings. The penultimate draft included a series of lessons on diarrhoea which had to be omitted due to length constraints. Ideally we would have liked to offer learners a choice between TB and Diarrhoea, but this was not possible due to publishing costs.

The materials were drafted and piloted with a group of teachers. The materials writer attended and participated in two classes on a regular basis. The lessons were discussed during weekly meetings with the teachers, and texts generated in the classes were collected and incorporated into the revisions of that draft as listening and reading texts. (See sample roleplays quoted earlier in this article.) Other texts, taken from magazines and books, were checked with teachers for their appropriateness. 
In the final analysis, it is the writer 'who must judge the possible relevance of materials, developed with 30 odd learning groups in a variety of contexts' (Kerfoot, 1993:441). However, there is a serious attempt to reflect learner and teacher voices within the materials. Once again, the extent to which the materials allow learners to develop their own voice and to accept or contest those reflected in the materials, rests largely on the teacher's ability to encourage critical analysis.

In these ways, 'Speak Out' has attempted to reconcile the tensions between participatory learner-centred education and the need for published materials which meet the requirements of a national curriculum and which can be used more widely. The generalisation of audience and the pre-selection of content was necessary for the development of a product for publication, the choice to present a structured learning process in the form of lesson plans, rather than a bank of learning resources, was necessary to address the realities of the teaching context and the level of teacher competence. However, the course actively seeks to develop teachers so that they can discard the course and create their own, and it seeks to encourage reflective and critical learning on the part of learners so that they can increasingly participate in and take control of the learning process.

\section{PUBLICATION AND IMPACT}

'Speak Out' was finally published in 1997 by Sached Books/Maskew Miller Longman, a national publishing house. One of the reasons why it took five instead of three years to complete was due to the period of transition and financial insecurity experienced by nongovernmental organisation after the 1994 elections. The work of organisations like Uswe, which worked outside the state system of 'night schools' for adults, was, throughout the eighties and early nineties, funded by overseas donors.

Unfortunately, the vision of a national ABET system failed to materialise post-1994, mostly due to a lack of resources. Foreign funding dried up after the 1994 elections and the new democratically elected government had other more pressing priorities such as job creation, health, housing, and primary education. As a result, the ABET sector has virtually collapsed and the lacking of funding for provision, including the purchase of materials, has led to the closure of a number of organisations which offered classes to adults. There is some hope that the new Minister of Education appointed in May of 1999 will revitalise ABET, but the question of resources remains. Whether or not 'Speak Out' is ever used in anything more a few local classes remains a question for the future.

\section{ACKNOWLEDGEMENTS}

Special acknowledgement to Kathleen Sutton, co-author of the Speak Out course. Without the teachers and learners, this course could not have been developed. Special thanks to Nomthinjana Makalima, Kenneth Mpengesi, Zelpha Ndeleni, Zelanga Nokuvela, Pumeza Zondani and Mercy Ntombana. Many of their teaching ideas have been incorporated. 
Thanks also to Caroline Kerfoot, Uswe's curriculum co-ordinator, who helped conceptualise and edit this course, and to both Caroline and Elsa Auerbach for comments on an earlier draft of this article.

Lastly, grateful thanks to the National Research Foundation for sponsoring my trip to the $32^{\text {nd }}$ Annual Conference of BAAL in Edinburgh in 1999 during which I presented a previous version of this article as a paper.

\section{ENDNOTES}

' The name 'Uswe' is an acronym for 'Using Spoken and Written English'. As the organisation's goals shifted from English literacy to broader educational, social and political goals, the name became inappropriate.

However, by then Uswe had established itself and so it was decided to retain the acronym but not to use the full name.

${ }^{2}$ I have chosen to use the term 'additional' rather than 'second' language as most adult learners speak more than two languages.

${ }^{3} \mathrm{ABE}$ became ABET in the early 1990s as the South African educational policy research (for the post-apartheid state) proposed the development of an overarching outcomes-based framework for education and training, the National Qualifications Framework (NQF). The NQF bas now been implemented under the post-apartheid government.

\section{REFERENCES}

AUERBACH, E. 1992. Making meaning making change. Washington DC: Center for Applied Linguistics, ERIC Clearinghouse.

CLIFFORD, M AND C KERFOOT. 1992. English: language of hope or broken dream. In Hutton B (ed.), Adult Basic Education in South Africa. Cape Town: Oxford University Press: 152-217.

CUMMINS, J AND M SWAIN. 1986. Bilingualism in Education. London: Longman.

FREIRE, P. 1972. Pedagogy of the Oppressed. Harmondsworth: Penguin

HARLEY, A, J AITCHISON, E LYSTER AND S LAND. 1996. A survey of adult basic education in South African in the 90s. Johannesburg: SACHED books.

KERFOOT, C. 1993. Participatory education in a South African context: contradictions and challenges. In TESOL Quarterly, 27(3): 431-447.

PRABHU, NS. 1987. Second language pedagogy. Cambridge: Cambridge University Press. 